\title{
BENTUK DAN MAKNA SUFIKS BAHASA KULISUSU
}

\section{THE MEANING AND FORM OF SUFFIX OF KULISUSU LANGUAGE}

\author{
Firman A.D. \\ Kantor Bahasa Provinsi Sulawesi Tenggara \\ Jalan Haluoleo, Kompleks Bumi Praja Anduonohu, Kendari, Indonesia \\ firmanad041@gmail.com
}

(Naskah diterima tanggal 23 Desember 2020, direvisi terakhir tanggal 16 Maret 2021, dan

disetujui tanggal 3 Mei 2021)

DOI: https:// doi.org/10.26499/wdprw.v49i1.723

\begin{abstract}
This research describes suffixes in Kulisusu language from the side of meaning and allomorph that is formed in the morphophonemic process. This research is descriptive-qualitative. Data analysis was used the referential (identity) method through sorting or classification based on the characteristics and description of the data. The meanings and evidence of morphophonemic in affixation were defined and compared to see its pattern so that can be categorized variation of suffix forms. According to the data analysis, there are 7 suffixes in Kulisusu languages. Suffix $\{-a\}$ have 11 allomorphs, suffix $\{-i\}$ have have 11 allomorphs, and suffix $\{$-ako\} have 10 allomorphs. Meanwhile, 4 suffixes, that are, $\{-o\}$ only have 2 allomorphs, \{-ano\} have 2 allomorphs. Suffix $\{-m o\}$ and $\{-n o\}$ respectively only has 1 allomorph. Those suffixes if attached to the base generally pertaining to the forming of the imperative verbs which have a meaning like 'do something', 'make something, and give into something'. Besides, it can also form nouns that meaning related to 'tool', 'place', and 'time'.
\end{abstract}

Keywords: Kulisusu language; suffix; morphophonemic; allomorph

\begin{abstract}
Abstrak
Penelitian ini mendeskripsikan sufiks bahasa Kulisusu dari segi makna dan alomorf yang terbentuk dalam proses morfofonemik. Penelitian ini bersifat kualitatif deskriptif. Dalam melakukan analisis data digunakan metode padan referensial melalui pemilahan atau pengklasifikasian berdasarkan ciri-ciri, sifat-sifat, dan gambaran data. Makna dan bukti-bukti morfofonemik dalam afiksasi didefinisikan dan dibandingkan untuk melihat pola yang terbentuk sehingga dapat dikategorikan variasi bentuk-bentuk sufiks. Hasil analisis data menunjukkan bahwa sufiks bahasa Kulisusu ada tujuh. Sufiks $\{-a\}$ memiliki 11 alomorf, sufiks \{-i\} memiliki 11 alomorf, dan sufiks \{-ako\} memiliki 10 alomorf. Sementara, empat sufiks lainnya, yaitu sufiks \{-o\} hanya memiliki 2 alomorf, sufiks \{-ano\} memiliki 2 alomorf, serta sufiks \{-mo\} dan \{-no\} masing-masing memiliki 1 alomorf. Sufiks-sufiks tersebut jika melekat pada bentuk dasar umumnya berkaitan dengan pembentukan verba imperatif yang bermakna 'melakukan pekerjaan, 'membuat sesuatu', dan 'memberi ke sesuatu'. Sufiks tersebut juga membentuk nomina yang maknanya berkaitan dengan 'alat', 'tempat' dan 'masa'.
\end{abstract}

Kata-kata Kunci: bahasa Kulisusu; sufiks; morfofonemik; alomorf

\section{Pendahuluan}

Bahasa Kulisusu merupakan salah satu bahasa daerah yang dituturkan di Provinsi
Sulawesi Tenggara. Penutur bahasa ini umumnya berada di wilayah Kabupaten Buton Utara. Selain di Buton Utara, penutur 
bahasa ini juga tersebar di beberapa daerah di Sulawesi Tenggara, di antaranya di Pulau Wawonii (sekarang Kabupaten Konawe Kepulauan), Kabupaten Muna, Kabupaten Buton, Kabupaten Wakatobi, dan sebagian kecil di Kota Kendari. Berdasarkan hasil Pemetaan Bahasa yang dilakukan oleh Pusat Bahasa (2008), bahasa Kulisusu terdiri atas empat dialek, yaitu dialek Kambowa, Taloki, Wawonii, dan dialek Ereke (hlm. 81). Penutur bahasa Kulisusu di Buton Utara dikelilingi oleh penutur dari beberapa bahasa daerah lain, seperti bahasa Muna, Ciacia, dan Wolio.

Berdasarkan sejarah, nama Kulisusu menjadi sebutan suatu unit pemerintahan yang dinamakan Barata Kulisusu, bagian dari pemerintahan Kesultanan Buton, yang terbentuk pada masa pemerintahan La Elangi yang menjadi Sultan Buton IV (1578--1615) (http://arum-sultra.blogspot.com/2011/02/, 2011). Selain, nama Kulisusu sebagai bahasa dan etnis, juga dikenal nama Lipu dan Ereke. Lipu menjadi pusat pemerintahan tempat berdirinya benteng dan Ereke menjadi pusat aktivitas dan ekonomi masyarakat yang saat ini menjadi ibu kota Kecamatan Kulisusu.

Dalam perkembangannya, bahasa Kulisusu masih menjadi bahasa pergaulan dan bahasa sehari-hari masyarakat di wilayah Buton Utara. Sejak dimekarkan tahun 2007 menjadi Kabupaten Buton Utara dari Kabupaten Muna, pemerintah daerah kurang memperhatikan keberadaan bahasa Kulisusu sebagai bahasa yang dituturkan oleh masyarakat setempat. Program kebijakan yang mendukung pengembangan bahasa Kulisusu hampir tidak pernah terdengar. Hal tersebut dapat dilihat dari tidak diajarkannya bahasa tersebut di sekolah-sekolah sebagai muatan lokal. Bahkan, pemerintah daerah jarang sekali melaksanakan kegiatan-kegiatan budaya yang seharusnya menggunakan bahasa Kulisusu sebagai bahasa pengantar adat. Pihak pemerintah daerah setempat saat ini masih berfokus ke pembangunan dan pengembangan fisik dan ekonomi.

Bahasa Kulisusu jarang sekali diteliti dan diangkat untuk dijadikan bahan diskusi ilmiah. Upaya pendokumentasian bahasa Kulisusu telah dilakukan oleh Mead (linguis Amerika) yang membuat Kamus Kulisusu (dalam tiga bahasa) sejak tahun 2000-2016. Selain itu, ada beberapa hasil penelitian yang dilakukan oleh mahasiswa dalam rangka penyelesaian studi sarjana yang berhasil didapatkan oleh peneliti dalam kaitannya dengan penelitian ini. Di antara penelitian tersebut adalah yang dilakukan oleh Asmi (1995) dengan judul "Sistem Afiksasi Bahasa Kulisusu". Penelitian tersebut mengemukakan afiks-afiks dalam bahasa Kulisusu beserta proses morfofonemiknya. Ia lebih cenderung mengelaborasi proses morfofonemik dalam prefiks sehingga kaidah-kaidah morfofonemik, termasuk alomorf, dalam sufiks terabaikan. Selain itu, beberapa makna sufiks belum terurai dengan gamblang (hlm. 4047). Kekurangan-kekurangan inilah yang akan diupayakan untuk dilengkapi dalam penelitian ini. Penelitian berikutnya adalah yang dilakukan oleh Roy (2007) dengan judul "Inflectional Verb in Kulisusu Language". Penelitian tersebut lebih khusus membahas afiks-afiks dan proses morfologis yang terjadi pada pembentukan verba infleksional bahasa Kulisusu, termasuk sufiks (hlm. 83-84)

Penelitian lain yang berkaitan dengan morfologi bahasa Kulisusu pernah ditulis oleh Sarmin (2015) dengan judul "Sistem Morfologi Nomina dalam Bahasa Kulisusu." Dalam penelitian itu lebih dikhususkan pada ciri, bentuk, fungsi, dan makna nomina bahasa Kulisusu (hlm. 7-8). Ada yang perlu diklarifikasi dalam penelitian itu mengenai unsur $\{$-no\} yang dimasukkan sebagai sufiks. Unsur $\{-$ no $\}$ memang dapat berfungsi sebagai sufiks dan juga klitika, tergantung pada kata yang dilekatinya. Beberapa contoh yang diberikan dalam penelitian itu mengenai 
sufiks $\{$-no\} sebenarnya tidak berfungsi sebagai sufiks, melainkan klitika. Jika melekat pada nomina, unsur tersebut berfungsi sebagai klitika yang memiliki makna pronominal persona dan pronominal benda yang menyatakan milik (dalam bahasa Indonesia dapat disejajarkan dengan klitika \{nya\}). Selain itu, sufiks \{-ha\} yang dikemukakan dalam penelitian tersebut sebenarnya hanyalah alomorf dari sufiks $\{-a\}$.

Berikutnya adalah tulisan yang berjudul "Infleksi Bahasa Kulisusu" yang ditulis oleh Ramsi (2017). Dalam penelitian ini disebutkan ada empat sufiks infleksi dalam bahasa Kulisusu, yaitu $\{-\mathrm{i}\},\{-\mathrm{o}\},\{-\mathrm{io}\}$, dan $\{-$ ako $\}$ (hlm. 7). Keempat sufiks tersebut juga akan dibahas dalam penelitian ini dan akan terlihat bahwa keempat sufiks tersebut bukan hanya sufiks infleksi melainkan juga dapat menjadi sufiks derivasi.

Ada penelitian menarik yang dilakukan oleh Asmadi (2016) dengan judul "Proses Morfologis pada Kultur Bahasa Samawa". Dalam penelitian tersebut dikemukakan bahwa orientasi nilai budaya etnis Samawa dapat ditelusuri melalui proses morfologis. Ada afiks-afiks tertentu yang dapat menggambarkan aktivitas budaya dalam etnis Samawa (hlm. 17-18). Dalam bahasa Kulisusu pun ada afiks-afiks khusus yang dapat menandakan aktivitas budaya khusus yang dilakukan oleh masyarakat Kulisusu berdasarkan beberapa contoh yang dipaparkan dalam pembahasan. Namun, dalam penelitian ini tidak menjadi fokus pembahasan.

Dalam kaitannya dengan pengembangan penelitian ini, "Analisis Morfofonemik Bahasa Melayu Jambi sebagai Pengembangan Bahan Ajar Morfologi Bahasa Indonesia" yang diteliti oleh Akhyaruddin, dkk. (2020) dapat menjadi masukan dalam mengelaborasi lebih lanjut penelitian ini. Tentunya, penelitian ini dapat menjadi bahan untuk berbagai materi, khususnya pembuatan dan pengayaan materi bahan ajar muatan lokal bahasa Kulisusu.

Berdasarkan hal tersebut, peneliti berupaya melengkapi hasil-hasil penelitian tersebut, khususnya afiks bahasa Kulisusu, dengan lebih berfokus pada aspek sufiks. Melalui tulisan ini dapat dielaborasi secara lengkap beberapa sufiks bahasa Kulisusu, termasuk makna yang terkandung dalam sufiks tersebut jika melekat pada bentuk dasar. Selain itu, juga dikemukakan beberapa variasi bentuk atau alomorf yang terjadi dari proses pengimbuhan sufiks dengan kata dasar. Sejalan dengan itu, tujuan penelitian ini adalah memaparkan dan mendeskripsikan beberapa sufiks bahasa Kulisusu beserta maknanya dan beberapa alomorf yang terbentuk melalui proses pengimbuhan sufiks.

Analisis mengenai afiks masuk dalam bidang kajian morfologi sebagai salah satu pembentuk kata dalam proses morfologi. Menurut Damayanti (2016) afiksasi ialah proses pembubuhan afiks (prefiks, sufiks, infiks, konfiks, dan simulfiks) pada bentuk dasar, baik bentuk dasar berupa kata dasar maupun bentuk dasar berupa kata turunan (hlm. 259).

Fokus pembahasan tulisan ini berkaitan dengan sufiks, yaitu salah satu jenis afiks yang jarang diurai dengan rinci proses morfofonemisnya dalam sebuah tulisan ilmiah, khususnya bahasa daerah. Sufiks dapat didefinisikan sebagai morfem terikat atau afiks yang dilekatkan di belakang, di akhir, atau di sebelah kanan bentuk dasar (lihat Chaer, 2015: 23 dan Putrayasa, 2017: 27).

Firman A.D. (2017) mengemukakan bahwa sebagian proses afiksasi yang terjadi akan berkaitan dengan variasi-variasi bentuk yang muncul dalam proses tersebut setelah diimbuhkan dengan bentuk terikat. Peristiwa tersebut disebabkan oleh adanya kondisi fonologis. Kondisi fonologis tersebut dapat menyebabkan terjadinya perubahan pada 
afiks yang diimbuhkan, dan ada juga yang tidak mengalami perubahan (hlm. 50 ).

Para ahli berpendapat bahwa persoalan pokok yang dibahas dalam proses morfofonemik adalah perubahan fonem yang terjadi sebagai akibat dari persinggungan morfem dengan morfem. Perbedaan para ahli dalam menyoroti proses morfofonemik hanyalah pada pelbagai jenis penggolongan sebagai akibat yang ditimbulkan karena persinggungan tersebut. Perbedaan itu dipengaruhi oleh perbedaan lambang morfem yang dipilih dan kuantittas data yang diperikan oleh tiaptiap ahli (Hidayat, 2018: 11-22).

Sugerman (2016) mengemukakan proses morfofonemik adalah proses peluluhan atau perubahan fonem akibat bertemunya morfem dasar dengan fonem-fonem tanpa mengubah makna dasarnya. Bentuk morfofonemik dapat berupa perubahan fonem, penambahan fonem, dan penghilangan fonem (hlm. 97-99).

Akibat proses morfofonemis menyebabkan munculnya berbagai bentuk variasi (atau lebih dikenal dengan alomorf) karena pengaruh lingkungan dari fonem yang ada dalam morfem. Mengenai alomorf secara ringkas dijelaskan oleh Parera, (2007) bahwa apabila sebuah morfem kadang-kadang diwakili oleh bangun fonemis tertentu sesuai lingkung-annya dan kadang-kadang pula diwakili oleh bangun fonemis yang lain, dikatakan bentuk-bentuk itu saling beralternasi. Tiap perwakilan dari sebuah morfem tertentu disebut alomorf. Dapat pula dikatakan alomorf ialah nama untuk bentukbentuk perwakilan dari sebuah morfem berdasarkan lingkungannya (hlm. 31).

Dalam kaitannya dengan penelitian ini, kerangka teori yang diterapkan berpangkal pada teori morfologi generatif dipadukan dengan teori fonologi generatif yang mengacu pada kaidah-kaidah morfofonologi atau morfofonemis (lihat Jerniati, 2017: hlm. 243). Morfofonemis terjadi ketika morfem-morfem bergabung untuk membentuk kata, segmen- segmen dari morfem-morfem yang berdekatan, berjejeran, dan kadang-kadang mengalami perubahan. Jadi, teori ini berimplikasi bahwa kaidah-kaidah morfofonemis yang dimaksud adalah kaidah perubahan bunyi dalam pembentukan kata, seperti perubahan bunyi asimilasi, penambahan, dan pelesapan fonem yang terjadi dalam proses morfologis. Dengan kata lain, morfofonemik adalah struktur bahasa yang menggambarkan pola fonologis dari morfem.

Menurut Sundasewu (2015) morfofonemik adalah gabungan dua cabang linguistik, yaitu morfologi dan fonologi/ fonemik. Bidang kajian morfofonemik ini meskipun biasanya dibahas dalam tataran morfologi, tetapi sebenarnya lebih banyak menyangkut masalah fonologi. Namun, kajian tentang morfofonemik ini tidak dibicarakan dalam tataran fonologi karena masalahnya baru akan muncul dalam kajian morfologi, terutama dalam proses afiksasi, reduplikasi, dan komposisi (hlm. 190).

Paryono (2010) mengemukakan bahwa kajian morfofonemik memiliki dua konsep dasar, yakni proses morfemis dan peristiwa fonemis. Proses morfemis merupakan pertemuan morfem dengan morfem, sementara peristiwa fonemis dipandang sebagai proses perubahan fonem akibat pertemuan morfem dengan morfem (hlm. 174-175).

Dalam kaitannya dengan penelitian ini, ada pandangan dari Parera (2007) yang menarik untuk diperhatikan. Ia mengemukakan bahwa beberapa alternasi dalam bahasa sering tidak dapat disistemkan dan diramalkan. Kenyataan ini membuktikan pula bahwa ada alternasi-alternasi yang berlangsung secara geografis dan bersifat perseorangan (dialektis atau idiolektis) (hlm. 37). Berdasarkan dugaan awal bahwa beberapa alomorf (alternasi) yang dihasilkan dalam proses morfefonemik sufiks bahasa 
Kulisusu tidak dapat disistemkan. Bahkan alomorf yang terbentuk cenderung terjadi secara sporadis.

\section{Metode Penelitian}

Penelitian ini bersifat kualitatif deskriptif. Penelitian kualitatif adalah penelitian yang bermaksud untuk memahami fenomena tentang apa yang dialami oleh subjek penelitian secara holistik, dan dengan cara deskripsi dalam bentuk kata-kata dan bahasa, pada suatu konteks khusus yang alamiah dan dengan memanfaatkan berbagai metode alamiah (Moleong, 2017: 6).

Bahan penelitian yang digunakan berupa data kebahasaan yang berasal dari sumber sekunder dan primer. Data sekunder merupakan data yang dijaring dari hasil studi pustaka, yaitu dari kamus, daftar kosakata, dan beberapa tulisan terkait, sebelum penelitian lapangan dilakukan. Data sekunder ini banyak peneliti peroleh melalui Kamus Kulisusu (Kulisusu-Indonesia-Inggris) yang disusun oleh Mead (2016) dan buku kumpulan Cerita Rakyat Kulisusu La Kino Nambo (Kantor Bahasa Sulawesi Tenggara, 2016) dan Cerita Rakyat Wawonii (Kantor Bahasa Sulawesi Tenggara, 2017).

Adapun data primer adalah data yang dijaring langsung dalam studi lapangan melalui para informan terpilih sebagai penutur asli bahasa Kulisusu yang dianggap dapat mewakili penutur bahasa yang diteliti. Para informan tersebut diwawancarai berdasarkan beberapa susunan daftar kosakata dan kalimat. Wawancara tersebut direkam untuk menghindari kesalahan pencatatan.

Metode dan teknik yang digunakan dalam pengumpulan data, yaitu metode simak dengan teknik catat dan rekam, metode cakap dengan teknik cakap semuka dan teknik catat. Penyimakan dilakukan dengan melihat penggunaan bahasa, baik secara lisan oleh informan maupun penggunaan bahasa tulis dalam beberapa data sekunder.

Dalam melakukan analisis data digunakan metode padan referensial (lihat Sudaryanto, 2015). Untuk mengoperasionalkan metode ini dilakukan pemilahan atau pengklasifikasian berdasarkan ciri-ciri, sifatsifat, dan gambaran data melalui klasifikasi data dalam proses afiksasi bahasa Kulisusu. Dalam penelitian ini juga dideskripsikan penemuan kaidah-kaidah yang berlaku umum dalam proses afiksasi bahasa Kulisusu. Untuk itu, bukti-bukti morfofenemik dalam afiksasi didefinisikan dan dibandingkan guna melihat pola-polanya. Berdasarkan hal tersebut, barulah dapat dikategorikan variasi bentuk-bentuk afiks dalam proses morfofonemik sufiks bahasa Kulisusu.

\section{Hasil dan Pembahasan}

Analisis morfologi dan morfofonemik atau afiksasi yang sangat umum dibahas adalah berkaitan dengan prefiks. Jarang ditemukan ada penelitian yang khusus membahas sufiks. Khusus bahasa-bahasa daerah Sulawesi Tenggara, pembentukan kata melalui sufiksasi sangat rumit untuk dijelaskan polapola yang terjadi dalam kaitannya dengan variasi bunyi yang terbentuk, khususnya dalam bahasa Kulisusu. Variasi bentuk atau penambahan fonem yang terjadi dalam morfofonemik sufiks bahasa Kulisusu cenderung terjadi secara acak dan agak rumit untuk dikaidahkan

Kesulitan untuk menjelaskan pola-pola pembentukan kata melalui sufiksasi disebabkan karena ciri bahasa Kulisusu sebagai bahasa vokalis atau semua kosakata berakhiran bunyi vokal. Sementara bunyi vokal yang ada umumnya sangat terbatas jumlahnya. Oleh karena itu, untuk menjelaskan pola dengan berdasarkan pada bunyi vokal yang terbatas tersebut pada akhir sebuah kata dasar yang diimbuhkan dengan sufiks biasanya disisipi oleh bunyi konsonan. 
Sisipan-sisipan bunyi konsonan inilah (umumnya posisi penultima) yang menyebabkan terjadinya pola variasi bentuk (alomorf) yang beragam dan terjadi secara sporadis. Dapat dikatakan terjadi secara manasuka, senyaman penutur mengucapkan dan menyisipkan bunyi konsonan (posisi penultima) di depan sufiks yang berciri vokal. Namun, ada juga sufiks yang memiliki pola secara teratur sebagaimana yang akan diuraikan selanjutnya.

Dalam penelitian ini, pendeskripsian variasi bentuk (alomorf) dalam proses penambahan sufiks terhadap bentuk dasar dalam bahasa Kulisusu dapat dijelaskan secara terperinci. Beberapa alomorf yang terbentuk dalam sufiksasi didasarkan pada bunyi vokal akhir dan bunyi sebelum vokal akhir yang ada pada bentuk dasar. Bahasa Kulisusu, sebagaimana bahasa-bahasa daerah lain di Sulawesi Tenggara, memiliki karakteristik sebagai bahasa berciri vokalis. Setiap kata diakhiri dengan bunyi vokal. Karena bunyi vokal lebih sedikit dibandingkan dengan bunyi konsonan, variasi alomorf yang terjadi dalam proses sufiksasi bahasa Kulisusu tidak sebanyak dalam proses prefiksasi.

Menurut Asmi (1995) afiks bahasa Kulisusu berjumlah 59 buah yang terdiri atas prefiks 29 buah, infiks 2 buah, sufiks 8 buah, konfiks 4 buah, dan gabungan imbuhan 16 buah. Kedelapan sufiks tersebut adalah $\{-\mathrm{a}\},\{-$ i\}, $\{-0\},\{-$ io $\},\{-\mathrm{mo}\},\{-\mathrm{no}\},\{-\mathrm{ano}\}$, dan $\{-\mathrm{ako}\}$ (hlm. 27-39). Dalam penelitian ini, sufiks yang dibahas hanya tujuh karena sufiks $\{$-io\} berasal dari perpaduan sufiks $\{-\mathrm{i}\}$ dan sufiks $\{-$ o\}. Hal ini akan dikemukakan pada bagian sufiks $\{-0\}$.

Berikut ini dikemukakan makna dan variasi bentuk yang terjadi dalam sufiks bahasa Kulisusu.

\subsection{Sufiks $\{-\mathbf{a}\}$}

Sufiks $\{-a\}$ merupakan salah satu afiks pembentuk nomina. Jika dilekatkan pada bentuk dasar, sufiks ini memiliki beberapa makna sebagai berikut.

'Tempat seperti yang tersebut dalam bentuk dasar'. Contoh;

$$
\begin{aligned}
& \text { pebaho }+\{-\mathrm{a}\}-\text { pebahoa } \\
& \text { 'mandi' } \begin{array}{c}
\text { 'tempat mandi' } \\
\text { pebue }+\{-\mathrm{a}\}-\text { pebuea }
\end{array}
\end{aligned}
$$

'mengayun' 'tempat menanggalkan ayunan'

rope $+\{-\mathrm{a}\}-$ ropea

'haluan, menuju' 'tujuan'.

'Alat atau perlengkapan'. Contoh;

pecinei $+\{-\mathrm{a}\}-$ pecineia

'menadah' 'alat untuk menadah air'

ewa $+\{-\mathrm{a}\}-$ ewanga

'kemauan berjuang' 'senjata, persenjataan'

tambe $+\{-\mathrm{a}\}-$ tambeanga

'bantal' 'bantalan'

'Hasil dari tindakan yang tersebut dalam

bentuk dasar'. Contoh;

curu $+\{-a\}-$ curupa

'menetes' 'tetesan'

pocia $+\{-\mathrm{a}\}-$ pociaa

'memberi' 'pemberian, pembagian'

pali $+\{-a\}-$ palinga

'gilir' 'giliran'

'Waktu atau masa'. Contoh;

bake $+\{-\mathrm{a}\}-$ bakea

'buah' 'waktu berbuah'

$i k i d i+\{-a\}-i k i d i h a$

'kecil' 'masa masih kecil'

poasa $+\{-\mathrm{a}\}-$ poasaa

'puasa' 'pembukaan/hari pertama puasa'.

Dalam proses morfofonemik, sufiks ini memiliki beberapa varian atau alomorf, bergantung pada fonem akhir yang dilekati. Berikut akan diuraikan varian-varian tersebut. 
Sufiks $\{-$ a $\}$ yang tidak mengalami perubahan pada bentuk jadian, misalnya;

\section{Tabel 1}

\begin{tabular}{lll}
\multicolumn{3}{c}{ Alomorf $\{$-a\} dari Sufiks $\{$-a $\}$} \\
\hline Bentuk Dasar & Alomorf & Bentuk Jadian \\
\hline pocuri 'tidur' & $\{$-a $\}$ & $\begin{array}{l}\text { pocuria 'tempat } \\
\text { tidur' }\end{array}$ \\
$\begin{array}{l}\text { boke 'sabung } \\
\text { ayam' } \\
\text { pobaca 'tempat } \\
\text { 'membaca' }\end{array}$ & $\{-\mathrm{a}\}$ & $\begin{array}{l}\text { sabung ayam' } \\
\text { pobacaa 'tempat } \\
\text { membaca' }\end{array}$ \\
\hline
\end{tabular}

Bentuk jadian mengalami penambahan fonem / $\mathrm{k} /$ jika bentuk dasar dilekati sufiks $\{$-a $\}$ sehingga variasi yang dihasilkan adalah $\{-k a\}$. Perhatikan beberapa contoh berikut.

\section{Tabel 2}

\begin{tabular}{|c|c|c|}
\hline \multicolumn{3}{|c|}{ Alomorf $\{-k a\}$ dari Sufiks $\{-a\}$} \\
\hline Bentuk Dasar & Alomorf & Bentuk Jadian \\
\hline sawi 'naik & $\{-\mathrm{ka}\}$ & sawika \\
\hline kendaraan' & & 'tumpangan' \\
\hline jepe 'berair' & $\{-\mathrm{ka}\}$ & $\begin{array}{l}\text { jepeka 'tanah } \\
\text { yang lunak dan } \\
\text { berair' }\end{array}$ \\
\hline popadi 'percik' & $\{-\mathrm{ka}\}$ & $\begin{array}{l}\text { popadika } \\
\text { 'percikan }\end{array}$ \\
\hline $\begin{array}{l}\text { pebaho } \\
\text { 'memandikan' }\end{array}$ & $\{-\mathrm{ka}\}$ & $\begin{array}{l}\text { banyak' } \\
\text { pebahoka 'waktu } \\
\text { mandi' }\end{array}$ \\
\hline
\end{tabular}

Jika sufiks $\{$-a\} dibubuhkan pada bentuk dasar yang umumnya berakhiran /a/ dan gugus vokal /ue/, kata jadian mengalami penambahan fonem /h/, sehingga alomorf yang dihasilkan adalah $\{$-ha\}. Perhatikan beberapa contoh berikut.

\section{Tabel 3}

\begin{tabular}{|c|c|c|}
\hline \multicolumn{3}{|c|}{ Alomorf $\{-h a\}$ dari Sufiks $\{-a\}$} \\
\hline Bentuk Dasar & Alomorf & Bentuk Jadian \\
\hline toora 'terang' & $\{-$ ha $\}$ & $\begin{array}{l}\text { tooraha 'tempat } \\
\text { terang' }\end{array}$ \\
\hline $\begin{array}{l}\text { poia 'tinggal, } \\
\text { terletak' }\end{array}$ & $\{-$ ha $\}$ & $\begin{array}{l}\text { poiaha 'tempat } \\
\text { tinggal' }\end{array}$ \\
\hline $\begin{array}{l}\text { dumaa 'ada, } \\
\text { berada' }\end{array}$ & $\{-$ ha $\}$ & $\begin{array}{l}\text { dumaaha } \\
\text { 'tempat berada' }\end{array}$ \\
\hline
\end{tabular}

$$
\begin{array}{lll}
\begin{array}{l}
\text { weweu } \\
\text { 'membuat' }
\end{array} \quad\{\text {-ha }\} \quad \begin{array}{l}
\text { weweuha } \\
\text { 'milik/barang } \\
\text { sendiri' }
\end{array} \\
\hline
\end{array}
$$

Sufiks $\{-$ a $\}$ mengalami penambahan fonem /t/ pada kata jadian. Alomorf yang terbentuk pada kata jadian adalah \{-ta\}. Berikut ini dikemukakan beberapa contoh.

\begin{tabular}{|c|c|c|}
\hline \multicolumn{3}{|c|}{ Alomorf $\{-$ ta $\}$ dari Sufiks $\{-a\}$} \\
\hline Bentuk Dasar & Alomorf & Bentuk Jadian \\
\hline $\begin{array}{l}\text { lapi 'sejenis } \\
\text { sarung' }\end{array}$ & $\{-$ ta $\}$ & lapita 'lipatan' \\
\hline olo (batas) & $\{-$ ta $\}$ & olota 'batasan' \\
\hline $\begin{array}{l}\text { kapii } \\
\text { 'penyakit' }\end{array}$ & $\{-$ ta $\}$ & $\begin{array}{l}\text { kapiita } \\
\text { 'mengalami } \\
\text { sakit' }\end{array}$ \\
\hline
\end{tabular}

\section{Tabel 4}

Jika sufiks $\{-\mathrm{a}\}$ dibubuhkan pada bentuk dasar, juga dapat menghasilkan variasi $\{-y a\}$ pada kata jadian. Berikut ini beberapa contohnya.

\section{Tabel 5}

\begin{tabular}{|c|c|c|}
\hline Bentuk Dasar & Alomorf & Bentuk Jadian \\
\hline $\begin{array}{l}\text { ewa 'kemauan } \\
\text { berjuang' }\end{array}$ & $\{-y a\}$ & $\begin{array}{l}\text { ewaya 'senjata, } \\
\text { persenitaan' }\end{array}$ \\
\hline $\begin{array}{l}\text { lowo 'areal, } \\
\text { tempat } \\
\text { berkebun' }\end{array}$ & $\{-y a\}$ & $\begin{array}{l}\text { lowoya } \\
\text { 'lapangan' }\end{array}$ \\
\hline pali 'gilir' & $\{-y a\}$ & paliga 'giliran' \\
\hline tambea 'bantal' & $\{-y a\}$ & $\begin{array}{l}\text { tambeaya } \\
\text { 'bantalan' }\end{array}$ \\
\hline
\end{tabular}

Alomorf $\{-y a\}$ dari Sufiks $\{-$ a $\}$

Berikut ini beberapa alomorf dari sufiks \{a) yang perubahan pada kata jadian hanya ditemukan satu contoh.

\section{Tabel 6}

\begin{tabular}{|c|c|c|}
\hline Bentuk Dasar & Alomorf & Bentuk Jadian \\
\hline bosi 'busuk' & $\{-1 a\}$ & $\begin{array}{l}\text { kabosila 'bau } \\
\text { busuk' }\end{array}$ \\
\hline bulu 'siram' & $\{-\mathrm{sa}\}$ & $\begin{array}{l}\text { bulusa 'tempat } \\
\text { menampung } \\
\text { air' }\end{array}$ \\
\hline сити & $\{-\mathrm{pa}\}$ & curupa 'tetesan' \\
\hline
\end{tabular}

Beberapa Alomorf dari Sufiks $\{-\mathrm{a}\}$ 


\begin{tabular}{|c|c|c|}
\hline kadu (kantong) & $\{-\mathrm{ma}\}$ & kaduma \\
\hline$u k i^{\prime} u k i r^{\prime}$ & $\{-$ ra $\}$ & $\begin{array}{l}\text { 'kandungan' } \\
\text { ukira 'ukiran' }\end{array}$ \\
\hline usu 'masuk' & $\{$-pia $\}$ & $\begin{array}{l}\text { usupia 'tempat } \\
\text { atau cara } \\
\text { masuk' }\end{array}$ \\
\hline
\end{tabular}

Pada tabel di atas terlihat bahwa sufiks $\{-\mathrm{a}\}$ dapat memiliki alomorf yang terjadi secara sporadis dan agak sulit untuk ditentukan polanya. Namun, kasus tersebut sangat terbatas (hanya ditemukan satu untuk setiap contoh). Sufiks $\{-$ a $\}$, selain pola yang sudah disebutkan sebelumnya, kadang-kadang dapat memiliki alomorf seperti yang disebutkan pada tabel di atas dengan bunyi konsonan (posisi penultima) yang menjadi pembeda.

\subsection{Sufiks $\{-\mathbf{i}\}$}

Umumnya, sufiks $\{-\mathrm{i}\}$ digunakan pada kalimat tanya, dan objek yang dikerjakan menunjukkan intensitas, baik dari segi kualitas maupun kuantitas. Sufiks $\{-i\}$ merupakan afiks pembentuk verba. Jika dibubuhkan pada kata dasar, sufiks ini memiliki beberapa makna yang dapat dilihat sebagai berikut.

'Melakukan perbuatan yang tersebut pada kata dasar dilakukan secara berulang.' Berikut ini beberapa contoh.

wete 'babat' $+\{-\mathbf{i}\}-$ weteki 'babati'

lemba 'pikul' $+\{-\mathrm{i}\}-$ lembari 'pikuli'

ewa 'lawan' $+\{-\mathrm{i}\}-$ ewangi 'lawan'

beru 'gores' $+\{-\mathbf{i}\}-$ berusi 'goresi'

'Memanggil atau mencari apa yang disebut pada bentuk dasarnya'. Contohnya dapat dilihat berikut ini.

lako 'pergi' $+\{-\mathrm{i}\}-$ lakosi 'pergi cari' leu 'datang' $+\{-\mathrm{i}\}-$ leusi 'datang cari'
'Melakukan pekerjaan atau perbuatan seperti yang tersebut pada bentuk dasarnya'. Lihat contoh berikut.

$a h u$ 'asap' $+\{-\mathrm{i}\}-a h u i$ 'asapi'

hulu 'terang' $+\{-\mathbf{i}\}-$ huluwi 'terangi'

cunu 'bakar' $+\{-\mathrm{i}\}-$ cunui 'bakar'

jaga 'jaga' + \{-i\}-jagai 'menjagai'

'Memberikan seperti yang tersebut pada bentuk dasarnya.' Contoh;

gamba 'ragi' $+\{-\mathrm{i}\}-$ gambai 'beri ragi'

ginta 'cabai' $+\{-\mathrm{i}\}-$ gintai 'beri cabai'

gara 'garam' $+\{-\mathbf{i}\}-$ garai 'garami'

cabo 'sabun' $+\{-\mathbf{i}\}-$ cabongi 'sabuni'

'Membuat atau menjadikan sesuatu seperti yang tersebut pada bentuk dasarnya.' Contoh;

limbu $+\{-\mathrm{i}\}-$ limburi

'bulat' 'menjadikan bulat'

locu $+\{-\mathbf{i}\}-$ locuki

'patah' 'menjadikan patah'

lomba $+\{-\mathrm{i}\}-$ lombangi

'lubang' 'membuat lubang'

Berdasarkan contoh tersebut dapat dilihat bahwa ada bentuk alomorf yang terjadi dalam sufiks ini jika dilekatkan pada bentuk dasar. Dalam pembentukannya, umumnya sufiks ini mengalami perubahan bentuk dan dipengaruhi oleh kondisi fonologis jika melekat pada kata dasar. Adapun varianvariannya ditampilkan dan dijelaskan sebagai berikut.

Sufiks $\{-i\}$ tidak mengubah bentuk jadian. Lihat contoh berikut.

\section{Tabel 7}

Alomorf $\{-\mathbf{i}\}$ dari Sufiks $\{-\mathbf{i}\}$

\begin{tabular}{lll}
\hline Bentuk Dasar & Alomorf & Bentuk Jadian \\
\hline $\begin{array}{l}\text { cundu } \\
\text { punggung } \\
\text { parang' }\end{array}$ & $\{-\mathrm{i}\}$ & $\begin{array}{l}\text { cundui 'pukul } \\
\text { dengan } \\
\text { punggung } \\
\text { parang' }\end{array}$ \\
\hline ciro 'lihat ke & $\{-\mathrm{i}\}$ & ciroi 'melihat ke
\end{tabular}




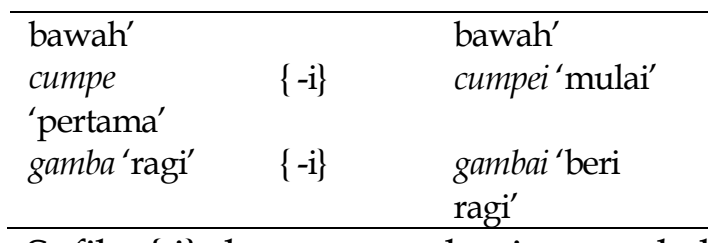

Sufiks $\{-i\}$ dapat mengalami penambahan fonem / w/ sehingga alomorf yang dihasilkan adalah $\{-$ wi $\}$. Perhatikan contoh berikut.

\section{Tabel 8}

\begin{tabular}{|c|c|c|}
\hline \multicolumn{3}{|c|}{ Alomorf $\{-w i\}$ dari Sufiks $\{-i\}$} \\
\hline Bentuk Dasar & Alomorf & Bentuk Jadian \\
\hline$a k u$ 'genggam' & $\{-w i\}$ & $\begin{array}{l}\text { akuwi 'ambil } \\
\text { dengan jumlah } \\
\text { banyak' }\end{array}$ \\
\hline leko (guling) & $\{$-wi $\}$ & $\begin{array}{l}\text { lekowi } \\
\text { 'bergelung, } \\
\text { melingkari' }\end{array}$ \\
\hline hulu (terang) & $\{-w i\}$ & huluwi 'terangi' \\
\hline
\end{tabular}

Sufiks $\{-\mathrm{i}\}$ dapat mengalami penambahan fonem / $\mathrm{k} /$ sehingga menghasilkan variasi bentuk $\{-\mathrm{ki}\}$ pada bentuk jadian.

\section{Tabel 9}

\begin{tabular}{|c|c|c|}
\hline \multicolumn{3}{|c|}{ Alomorf $\{-k i\}$ dari Sufiks $\{-\mathbf{i}\}$} \\
\hline Bentuk Dasar & Alomorf & Bentuk Jadian \\
\hline bincu & $\{-\mathrm{ki}\}$ & bincuki \\
\hline $\begin{array}{l}\text { 'mencabut' } \\
\text { uhu 'sengatan, } \\
\text { menusuk/me } \\
\text { nyuntik' }\end{array}$ & $\{-\mathrm{ki}\}$ & $\begin{array}{l}\text { 'mencabuti' } \\
\text { uhuki } \\
\text { 'menusuki' }\end{array}$ \\
\hline $\begin{array}{l}\text { sala 'salah, } \\
\text { beda' }\end{array}$ & $\{-\mathrm{ki}\}$ & $\begin{array}{l}\text { pekasalaki } \\
\text { 'berselisih, } \\
\text { bersalah }\end{array}$ \\
\hline sawi (naik) & $\{-\mathrm{ki}\}$ & $\begin{array}{l}\text { paham' } \\
\text { sawiki } \\
\text { 'menumpangi, } \\
\text { menaiki' }\end{array}$ \\
\hline $\begin{array}{l}\text { wonse 'cungkil } \\
\text { dgn jari' }\end{array}$ & $\{-\mathrm{ki}\}$ & $\begin{array}{l}\text { wonseki } \\
\text { 'mencungkil' }\end{array}$ \\
\hline
\end{tabular}

Sufiks $\{-\mathrm{i}\}$ dapat berubah menjadi $\{-$ si $\}$ jika dilekatkan pada bentuk dasar. Lihat contoh berikut.

\section{Tabel 10}

Alomorf \{-si\} dari Sufiks $\{-\mathbf{i}\}$

\begin{tabular}{|c|c|c|}
\hline Bentuk Dasar & Alomorf & Bentuk Jadian \\
\hline bolo 'ganti' & $\{-\mathrm{si}\}$ & $\begin{array}{l}\text { bolosi } \\
\text { 'mengganti' }\end{array}$ \\
\hline bulu 'siram' & $\{-\mathrm{si}\}$ & bulusi 'sirami' \\
\hline gigi 'parut' & $\{-\mathrm{si}\}$ & $\begin{array}{l}\text { gigisi 'mengikis, } \\
\text { menggosok' }\end{array}$ \\
\hline lako 'pergi' & $\{-\mathrm{si}\}$ & $\begin{array}{l}\text { lakosi } \\
\text { 'mengunjungi' }\end{array}$ \\
\hline $\begin{array}{l}\text { leu 'datang, } \\
\text { tiba' }\end{array}$ & $\{-\mathrm{si}\}$ & $\begin{array}{l}\text { leusi'datang } \\
\text { mengunjungi' }\end{array}$ \\
\hline
\end{tabular}

Sufiks $\{-\mathbf{i}\}$ dapat memiliki variasi menjadi $\{-n i\}$ Perhatikan contoh berikut.

Tabel 11

Alomorf $\{-$ yi $\}$ dari Sufiks $\{-\mathbf{i}\}$

\begin{tabular}{|c|c|c|}
\hline Bentuk Dasar & Alomorf & Bentuk Jadian \\
\hline $\begin{array}{l}\text { boru 'daun } \\
\text { lebar, kardus } \\
\text { yang } \\
\text { digunakan } \\
\text { sebagai } \\
\text { payung' }\end{array}$ & $\{-n i\}$ & $\begin{array}{l}\text { boruyi } \\
\text { 'payungi' }\end{array}$ \\
\hline cura 'longsor' & $\{-n i\}$ & $\begin{array}{l}\text { curayi } \\
\text { 'melongsorkan' }\end{array}$ \\
\hline lomba 'lubang' & $\{-y i\}$ & $\begin{array}{l}\text { lombayi } \\
\text { 'melubangi' }\end{array}$ \\
\hline rende 'getar' & $\{-\eta \mathrm{i}\}$ & $\begin{array}{l}\text { rendeyi } \\
\text { 'bergetar' }\end{array}$ \\
\hline risi 'cepat' & $\{-\eta \mathbf{i}\}$ & $\begin{array}{l}\text { risini } \\
\text { 'mempercepat' }\end{array}$ \\
\hline
\end{tabular}

Sufiks $\{-i\}$ dapat memiliki bentuk variasi $\{-$ ri\} pada bentuk jadian. Lihat contoh berikut.

Tabel 12

Alomorf \{-ri\} dari Sufiks $\{-\mathbf{i}\}$

\begin{tabular}{|c|c|c|}
\hline Bentuk Dasar & Alomorf & Bentuk Jadian \\
\hline cuka 'tukar' & $\{-$ ri $\}$ & $\begin{array}{l}\text { cukari } \\
\text { 'menukar' }\end{array}$ \\
\hline hule 'gasing' & $\{-$-ri $\}$ & huleri 'mabuk' \\
\hline limbu 'bulat' & $\{-$-ri $\}$ & $\begin{array}{l}\text { limburi } \\
\text { 'membuat } \\
\text { bulat' }\end{array}$ \\
\hline pio 'peras' & $\{-$ ri $\}$ & $\begin{array}{l}\text { piori'menetesi } \\
\text { dgn cara } \\
\text { peras' }\end{array}$ \\
\hline
\end{tabular}


Sufiks $\quad\{-i\}$ dapat mengalami penambahan fonem /p/ dalam proses morfofonemik sehingga alomorf yang dihasilkan adalah $\{-$ pi\}. Lihat contoh berikut.

Tabel 13

Alomorf $\{-$ pi\} dari Sufiks $\{-\mathbf{i}\}$

\begin{tabular}{lll}
\hline Bentuk Dasar & Alomorf & Bentuk Jadian \\
\hline curu'menetes' & $\{$-pi\} & $\begin{array}{l}\text { curupi } \\
\text { 'menetesi, } \\
\text { menitikkan } \\
\text { pada' } \\
\text { ondapi }\end{array}$ \\
onda 'sisik' & $\{$-pi $\}$ & $\begin{array}{l}\text { 'menyisiki' } \\
\text { salupi 'sejenis } \\
\text { tikar dari } \\
\text { pandan' } \\
\text { salu'pengalas }\end{array}$ \\
$\begin{array}{l}\text { belanga dari } \\
\text { tanah liat' }\end{array}$ & $\{$-pi $\}$ & 'memasuki' \\
usu'masuk' & $\{$-pi $\}$ & \\
\hline
\end{tabular}

Sufiks $\{-i\}$ dapat memiliki variasi menjadi $\{-n i\}$ pada bentuk jadian.

Tabel 14

Alomorf $\{-$ ni $\}$ dari Sufiks $\{-\mathbf{i}\}$

\begin{tabular}{|c|c|c|}
\hline Bentuk Dasar & Alomorf & Bentuk Jadian \\
\hline cuuna 'jatuh' & $\{-\mathrm{ni}\}$ & cuunani \\
\hline $\begin{array}{l}\text { halau 'salah, } \\
\text { utang' }\end{array}$ & $\{-\mathrm{ni}\}$ & $\begin{array}{l}\text { halauni 'nazar, } \\
\text { janjian, ucapan } \\
\text { terima kasih } \\
\text { kpd Tuhan' }\end{array}$ \\
\hline $\begin{array}{l}\text { kompo 'usus, } \\
\text { isi perut' }\end{array}$ & $\{-n i\}$ & $\begin{array}{l}\text { komponi } \\
\text { 'mengeluarkan } \\
\text { isi perut' }\end{array}$ \\
\hline $\begin{array}{l}\text { orima } \\
\text { 'disayangkan' }\end{array}$ & $\{-n i\}$ & $\begin{array}{l}\text { orimani } \\
\text { 'menghemat' }\end{array}$ \\
\hline
\end{tabular}

Sufiks $\{-i\}$ dapat mengalami penambahan fonem /c/ pada bentuk jadian sehingga variasi yang dihasilkan adalah $\{-\mathrm{ci}\}$.

Tabel 15

\begin{tabular}{|c|c|c|}
\hline \multicolumn{3}{|c|}{ Alomorf $\{-c i\}$ dari Sufiks $\{-i\}$} \\
\hline Bentuk Dasar & Alomorf & Bentuk Jadian \\
\hline 'kula & $\{-\mathrm{ci}\}$ & $\begin{array}{l}\text { kulaci } \\
\text { 'memanaskan } \\
\text { kembali' }\end{array}$ \\
\hline
\end{tabular}

\begin{tabular}{|c|c|c|}
\hline laa 'jarang' & $\{-\mathrm{ci}\}$ & laaci \\
\hline longka'terbuka & $\{-\mathrm{ci}\}$ & $\begin{array}{l}\text { 'menjarangkan' } \\
\text { longkaci }\end{array}$ \\
\hline & & 'membuka \\
\hline lengketannya' & & $\begin{array}{l}\text { sesuatu yang } \\
\text { lengket' }\end{array}$ \\
\hline рерии (antah) & $\{-\mathrm{Ci}\}$ & рериисі \\
\hline & & $\begin{array}{l}\text { 'menyortir, } \\
\text { memisah- } \\
\text { misahkan' }\end{array}$ \\
\hline
\end{tabular}

Sufiks $\{-i\}$ dapat berubah menjadi $\{-\mathrm{mi}\}$ pada bentuk jadian. Lihat contoh berikut.

Tabel 16

\begin{tabular}{|c|c|c|}
\hline \multicolumn{3}{|c|}{ Alomorf $\{-\mathrm{mi}\}$ dari Sufiks $\{-\mathrm{i}\}$} \\
\hline Bentuk Dasar & Alomorf & Bentuk Jadian \\
\hline olu 'awan' & $\{-\mathrm{mi}\}$ & olumi \\
\hline $\begin{array}{l}\text { roda 'capai, } \\
\text { dapat' }\end{array}$ & $\{-\mathrm{mi}\}$ & rodami \\
\hline $\begin{array}{l}\text { sansa 'lewat, } \\
\text { melanggar' }\end{array}$ & $\{-\mathrm{mi}\}$ & $\begin{array}{l}\text { sansami } \\
\text { 'melewati' }\end{array}$ \\
\hline
\end{tabular}

Sufiks $\{-i\}$ dapat memiliki variasi menjadi $\{$-li\} pada bentuk jadian. Lihat contoh berikut.

Tabel 17

\section{Alomorf $\{-1 i\}$ dari Sufiks $\{-i\}$}

\begin{tabular}{lll}
\hline Bentuk Dasar & Alomorf & Bentuk Jadian \\
\hline $\begin{array}{l}\text { kuso 'meremas } \\
\text { sambil }\end{array}$ & $\{$-li\} & $\begin{array}{l}\text { kusoli 'memeras } \\
\text { dengan tangan' } \\
\text { memeras' }\end{array}$ \\
$\begin{array}{l}\text { tampo } \\
\text { 'menambal, }\end{array}$ & $\{$-li\} & $\begin{array}{l}\text { kantampoli } \\
\text { menyumbat }\end{array}$ \\
$\begin{array}{l}\text { aliran' } \\
\text { engka 'angkat' }\end{array}$ & $\{$-li $\}$ & engkali 'angkati' \\
\hline
\end{tabular}

\subsection{Sufiks $\{-0\}$}

Sufiks ini berfungsi membentuk kelas verba. Arti dari sufiks ini jika melekat pada bentuk dasar adalah menyatakan arti 'perintah melakukan pekerjaan seperti yang disebut oleh bentuk dasarnya atau menekankan makna kata yang di depannya dalam bentuk perintah'. Contohnya dapat dilihat sebagai berikut. 
pepe 'pukul' $+\{-\mathrm{o}\}-$ pepeho 'pukuli'

beto $+\{-\mathrm{o}\}-$ betoo 'tusuk'

'duri pada ikan pari'

alumi $+\{-\mathrm{o}\}$-alumio 'lindungi'

'menaungi, melindungi'

kiki $+\{-o\}-k i k i o$ 'gigit'

'menggigit'

Sufiks ini memiliki variasi bentuk atau alomorf hanya dua jenis, yaitu $\{-\mathrm{o}\}$ dan $\{-$ ho $\}$. Berikut ini beberapa contoh dari bentuk tersebut.

Sufiks $\{-o\}$ tidak mengubah kata jadian jika kata dasar yang dilekatinya diakhiri dengan fonem vokal /i/, /u/, /o/, /e/, /a/ yang didahului oleh konsonan $/ \mathrm{r} /$.

Tabel 18

\section{Alomorf $\{-0\}$ dari Sufiks $\{-0\}$}

\begin{tabular}{lll}
\hline Bentuk Dasar & Alomorf & Bentuk Jadian \\
\hline $\begin{array}{l}\text { cia 'memberi' } \\
\text { cindi }\end{array}$ & $\{-\mathrm{o}\}$ & $\begin{array}{l}\text { ciao 'berikan' } \\
\text { cindio 'putar' }\end{array}$ \\
$\begin{array}{l}\text { 'memutar' } \\
\text { kopo }\end{array}$ & $\{-\mathrm{o}\}$ & $\begin{array}{l}\text { kopoo } \\
\text { 'menggengga }\end{array}$ \\
$\mathrm{m}^{\prime}$
\end{tabular}

Sufiks $\{-o\}$ berubah menjadi $\{-h o\}$ jika kata dasar yang dilekatinya diakhiri dengan fonem vokal /u/, /i/.

Tabel 19

Alomorf $\{-$ ho $\}$ dari Sufiks $\{-0\}$

\begin{tabular}{lll}
\hline Bentuk Dasar & Alomorf & Bentuk Jadian \\
\hline $\begin{array}{l}\text { 'amo } m e n a n a m ' \\
\text { aru }\end{array}$ & $\{$-ho & lamoho 'tanam' \\
$\begin{array}{l}\text { 'menyentuh' } \\
\text { bensi }\end{array}$ & $\{-$ ho $\}$ & aruho 'sentuh' \\
$\begin{array}{l}\text { 'membuka } \\
\text { dgn gigit' }\end{array}$ & $\{-$ ho $\}$ & bensiho 'buka' \\
$\begin{array}{l}\text { kare } \\
\text { 'mencakar' }\end{array}$ & $\{-$ ho $\}$ & kareho 'cakar' \\
\hline
\end{tabular}

Dalam prosesnya, afiks ini biasa berkombinasi dengan sufiks $\{-i\}$ yang umum digunakan sebagai afiks pada kalimat tanya, dan objek yang dikerjakan menunjukkan intensitas, baik dari segi kualitas maupun kuantitas. Untuk membentuk unsur atau kalimat perintah ditambahkanlah sufiks $\{-o\}$ yang objeknya menyatakan banyak (lihat Asmi, 1995). Perhatikan contoh berikut.

$e e+\{-\mathrm{i}\}-e e i+\{-\mathrm{o}\}-e e i o$

'air' 'mengairi' 'airi'

bingku $+\{-\mathbf{i}\}$-bingkuni $+\{-\mathrm{o}\}-$ bhingkunio

'pacul' 'memaculi' 'paculi'

sambu $+\{-\mathrm{i}\}-$ samburei $+\{-\mathrm{o}\}-$ sambureio

'sapu' 'menyapu' 'sapui'

Bandingkan beberapa kalimat berikut.

Yohapa u engkali iko?

'Apa yang engkau angkat itu?' (objeknya banyak)

Engkalio moi-moiko keuhako aiko!

'Angkat baik-baik kayu-kayu itu!'

Yohapa u engka iko?

'Apa yang engkau angkat itu?" (objeknya tunggal)

Engkao moi-moiko keu aiko!

'Angkat baik-baik kayu itu!'

\subsection{Sufiks \{-ako\}}

Sufiks ini berfungsi membentuk kelas verba.

Jika dilekatkan pada kata dasar, sufiks ini

memiliki beberapa makna sebagai berikut.

'Menjadikan seperti yang tersebut pada kata dasar', contohnya;

maasi $+\{$-ako $\}-$ maasiako

'sayang' 'menyayangi'

banga $+\{$-ako $\}$ - bangahako

'heran' 'menjadi heran pada'

ehe $+\{$-ako $\}-$ ehesako

'ingin, suka' 'membolehkan'

halo $+\{$-ako $\}-$ pohaloako

'hitam' 'menghitamkan' 
'Melakukan pekerjaan seperti yang disbutkan pada kata dasar', contohnya;

bulu $+\{$-ako $\}-$ bulusako

'siram' 'menyiramkan'

jumpa $+\{$-ako $\}$ - jumpalako

'tabrak' 'mendorong, menabrak'

suu $+\{$-ako $\}$ - suumako

'junjung' 'menjunjung'

cuda $+\{$-ako $\}$ - cudapako

'lempar' 'melemparkan berkali-kali'

dampi + \{-ako\} - dampitako

'lekat, lengket' ‘simpan kembali'

Sufiks ini memiliki variasi bentuk atau alomorf beberapa jenis. Berikut ini beberapa alomorf dari sufiks $\{$-ako\}.

Sufiks $\{$-ako\} tidak mengubah kata jadian yang dilekatinya. Perhatikan contoh berikut.

Tabel 20

\begin{tabular}{|c|c|c|}
\hline \multicolumn{3}{|c|}{ Alomorf $\{$-ako\} dari Sufiks $\{$-ako\} } \\
\hline Kata Dasar & Alomorf & Bentuk Jadian \\
\hline $\begin{array}{l}\text { maasi } \\
\text { 'sayang' }\end{array}$ & $\{$-ako $\}$ & $\begin{array}{l}\text { maasiako } \\
\text { 'sayang kepada, } \\
\text { mengasihi' }\end{array}$ \\
\hline basi 'tukar' & $\{$-ako $\}$ & $\begin{array}{l}\text { basiako } \\
\text { 'membuang' }\end{array}$ \\
\hline hala (salah) & $\{$-ako $\}$ & $\begin{array}{l}\text { halaako 'salah } \\
\text { tentang' }\end{array}$ \\
\hline hawi 'tabur' & $\{$-ako $\}$ & $\begin{array}{l}\text { hawiako } \\
\text { 'menabur' }\end{array}$ \\
\hline
\end{tabular}

Sufiks \{-ako\} mengalami penambahan fonem / h/ jika dilekatkan pada bentuk dasar. Bentuk yang dihasilkan adalah \{-hako\}. Perhatikan contoh berikut.

\section{Tabel 21}

\begin{tabular}{|c|c|c|}
\hline \multicolumn{3}{|c|}{ Alomorf $\{$-hako\} dari Sufiks $\{$-ako\} } \\
\hline Bentuk Dasar & Alomorf & Bentuk Jadian \\
\hline ia`bel & $\{$-hako\} & $\begin{array}{l}\text { ciahako } \\
\text { 'memberikan' }\end{array}$ \\
\hline $\begin{array}{l}\text { mongkocu } \\
\text { 'petik, panen' }\end{array}$ & $\{$-hako $\}$ & $\begin{array}{l}\text { mongkocuhako } \\
\text { 'memanen' }\end{array}$ \\
\hline
\end{tabular}

\begin{tabular}{lll}
$\begin{array}{l}\text { suere 'beda, } \\
\text { lain, asing' }\end{array}$ & $\{$-hako\} & $\begin{array}{l}\text { suerehako } \\
\text { 'mengganti, } \\
\text { menukar } \\
\text { dengan yang }\end{array}$ \\
$\begin{array}{l}\text { limpuru } \\
\text { turun) } \\
\text { ense'pindah' }\end{array}$ & $\{$-hako\} & $\begin{array}{l}\text { timpuruhako } \\
\text { 'menurun' } \\
\text { ensehako } \\
\text { 'pindahkan' }\end{array}$ \\
\hline
\end{tabular}

Sufiks \{-ako\} dapat berubah menjadi \{-pako\} pada kata jadian. Lihat contoh berikut.

Tabel 22

\begin{tabular}{|c|c|c|}
\hline \multicolumn{3}{|c|}{ Alomorf $\{-$ pako\} dari Sufiks $\{$-ako\} } \\
\hline Bentuk Dasar & Alomorf & Bentuk Jadian \\
\hline uda & $\{-$ pako\} & cudapako \\
\hline ‘melemparkan & & $\begin{array}{l}\text { 'melemparkan } \\
\text { beberapa kali' }\end{array}$ \\
\hline cuo 'tusuk' & $\{$-pako\} & $\begin{array}{l}\text { cuopako } \\
\text { 'menusukkan' }\end{array}$ \\
\hline kai ‘mengait' & $\{$-pako $\}$ & $\begin{array}{l}\text { kaipako } \\
\text { 'menggantung }\end{array}$ \\
\hline sidu 'sendok' & $\{$-pako $\}$ & $\begin{array}{l}\text { kan pada kait' } \\
\text { sidupako }\end{array}$ \\
\hline & & $\begin{array}{l}\text { 'menyekop } \\
\text { sesuatu' }\end{array}$ \\
\hline tanda & $\{$-pako $\}$ & tandapako \\
\hline (jongkok) & & 'menjongkok' \\
\hline usu 'masuk' & $\{$-pako $\}$ & $\begin{array}{l}\text { usupako } \\
\text { 'memasukkan' }\end{array}$ \\
\hline
\end{tabular}

Sufiks $\{$-ako\} juga memiliki variasi $\{$-sako\} jika dilekatkan pada bentuk dasar.

\section{Tabel 23}

\section{Alomorf \{-sako\} dari Sufiks \{-ako\}}

\begin{tabular}{lll}
\hline Bentuk Dasar & Alomorf & Bentuk Jadian \\
\hline $\begin{array}{l}\text { ehe 'ingin, } \\
\text { mau, suka' }\end{array}$ & $\begin{array}{l}\text {-sako }\} \\
\text { lomba 'lubang' }\end{array}$ & $\begin{array}{l}\text { ehesako } \\
\text { 'membolehkan, } \\
\text { mengizinkan' }\end{array}$ \\
$\begin{array}{l}\{\text {-sako }\} \\
\text { pau'tuang' }\end{array}$ & $\begin{array}{l}\text { lombasako } \\
\text { 'mengeluarkan' } \\
\text { pausako } \\
\text { 'menuangkan' }\end{array}$ \\
$\begin{array}{l}\text { 'bangun' } \\
\text { bue 'ayun' }\end{array}$ & $\{$-sako $\}$ & $\begin{array}{l}\text { wangusako } \\
\text { 'membangunkan' } \\
\text { buesako }\end{array}$ \\
\hline
\end{tabular}


Bentuk jadian dapat mengalami penambahan fonem /1/ jika sufiks $\{$-ako\} diimbuhkan pada bentuk dasar sehingga variannya menjadi \{-lako\}. Perhatikan contoh berikut.

\section{Tabel 24}

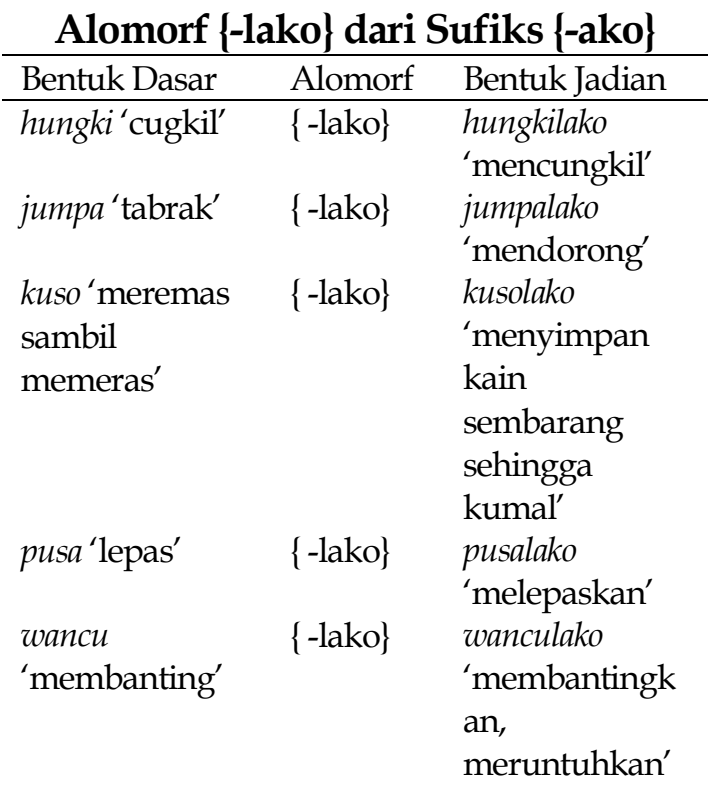

Sufiks \{-ako\} memiliki variasi bentuk \{-tako\} jika diimbuhkan pada bentuk dasar. Lihat contoh berikut.

\section{Tabel 25}

Alomorf \{-tako\} dari Sufiks \{-ako\}

\begin{tabular}{|c|c|c|}
\hline Bentuk Dasar & Alomorf & Bentuk Jadian \\
\hline $\begin{array}{l}\text { dampi } \\
\text { 'berlekat, } \\
\text { melengket' }\end{array}$ & $\{$-tako $\}$ & $\begin{array}{l}\text { dampitako } \\
\text { 'simpan ulang' }\end{array}$ \\
\hline pinai & $\{$-tako $\}$ & pinaitako \\
\hline $\begin{array}{l}\text { 'menurun' } \\
\text { poone 'naik, } \\
\text { panjat' }\end{array}$ & $\{$-tako $\}$ & $\begin{array}{l}\text { 'menurunkan' } \\
\text { poonetako } \\
\text { 'menaikkan' }\end{array}$ \\
\hline
\end{tabular}

Sufiks $\{$-ako\} dapat berubah menjadi $\{-$ kako\} jika dilekatkan pada bentuk dasar. Lihat contoh berikut.
Tabel 26

Alomorf \{-kako\} dari Sufiks \{-ako\}

\begin{tabular}{lll}
\hline Bentuk Dasar & Alomorf & Bentuk Jadian \\
\hline $\begin{array}{l}\text { hempi } \\
\text { 'melepaskan }\end{array}$ & $\{$-kako\} & $\begin{array}{l}\text { hempikako } \\
\text { 'melepaskan' }\end{array}$ \\
$\begin{array}{l}\text { batangnya } \\
\text { /kelopaknya' }\end{array}$ & & \\
rabe'putus' & $\{-$ kako $\}$ & $\begin{array}{l}\text { rabekako } \\
\text { 'memutus' }\end{array}$ \\
& & \\
\hline
\end{tabular}

Sufiks $\{$-ako\} berubah menjadi $\{$-rako\} jika diimbuhan pada bentuk dasar. Perhatikan contoh berikut.

\section{Tabel 27}

\begin{tabular}{lll}
\multicolumn{2}{c}{ Alomorf $\{$-rako\} dari } & Sufiks $\{$-ako\} \\
\hline Bentuk Dasar & Alomorf & Bentuk Jadian \\
\hline tau 'turun' & $\{$-rako\} & $\begin{array}{l}\text { taurako } \\
\text { 'menurunkan } \\
\text { pelan-pelan' }\end{array}$ \\
tompa 'batas' & $\{$-rako\} & $\begin{array}{l}\text { tomparako } \\
\text { 'sampai batas' }\end{array}$ \\
gogi 'gesek' & $\{$-rako\} & $\begin{array}{l}\text { gogirako } \\
\text { 'menggesekkan' }\end{array}$ \\
\hline
\end{tabular}

Sufiks $\{$-ako\} memiliki variasi bentuk menjadi \{-mako\} jika diimbuhkan pada kata dasar. Lihat contoh berikut.

\section{Tabel 28}

Alomorf \{-mako\} dari Sufiks \{-ako\}

\begin{tabular}{|c|c|c|}
\hline Bentuk Dasar & Alomorf & Bentuk Jadian \\
\hline Suu 'junjung' & $\{-$ mako $\}$ & suumako \\
\hline sansa (lewat) & $\{$-mako $\}$ & $\begin{array}{l}\text { sansamako } \\
\text { 'lewatkan' }\end{array}$ \\
\hline
\end{tabular}

Beberapa variasi dari sufiks \{-ako\} yang contoh sangat terbatas (hanya ditemukan satu contoh). Sufiks \{-ako\} memiliki variasi bentuk menjadi $\{$-nako\} dan $\{$-wako\}. Lihat contoh berikut. 
Tabel 29

Beberapa Alomorf Lain dari Sufiks $\{$-ako\}

\begin{tabular}{lll}
\hline Bentuk Dasar & Alomorf & Bentuk Jadian \\
\hline bansule & $\{$-yako\} & $\begin{array}{l}\text { bansuleyako } \\
\text { 'memulangkan, } \\
\text { mengembalikan } \\
\text { ke rumah' }\end{array}$ \\
sa (kumpul) & $\{$-wako\} & $\begin{array}{l}\text { sawako } \\
\text { 'kumpulkan' }\end{array}$ \\
\hline
\end{tabular}

Seperti pada sufiks $\{-a\}$, yang telah dijelaskan sebelumnya, sufiks \{-ako\} juga memiliki alomorf yang terjadi secara sporadis sehingga sulit ditentukan polanya (seperti pada tabel 29). Namun, kasus tersebut sangat terbatas (hanya ditemukan satu untuk setiap contoh). Bunyi konsonan pada posisi penultima (/w/ dan $/ y /$ ) yang menjadi pembeda sehingga membentuk alomorf berbeda.

\subsection{Sufiks $\{-\mathrm{mo}\}$}

Sufiks ini berfungsi untuk membentuk kelas adverbia. Makna dari sufiks ini jika dilekatkan pada kata dasar ada 'menekankan pekerjaan sudah dilakukan sebagaimana yang tersebut pada bentuk dasarnya'. Perhatikan beberapa contoh berikut.

$$
\begin{aligned}
& \text { waraka }+\{-\mathrm{mo}\}-\text { warakamo } \\
& \text { 'sehat' 'sudah sehat' } \\
& \text { mosao }+\{-\mathrm{mo}\}-\text { mosaomo } \\
& \text { 'jelek' } \quad \text { sudah jelek' } \\
& \text { polai }+\{-\mathrm{mo}\}-\text { polaimo } \\
& \text { 'lari' 'sudah lari' } \\
& \text { opicu }+\{-\mathrm{mo}\}-\text { opicumo } \\
& \text { 'tujuh' 'sudah tujuh' }
\end{aligned}
$$

Sufiks ini jika diimbuhkan ke kata dasar hanya memiliki satu jenis alomorf. Lihat beberapa contoh berikut.

mewohi $+\{-\mathrm{mo}\}-$ mewohimo

'kenyang' 'sudah kenyang'

bansule $+\{-\mathrm{mo}\}-$ bansulemo

'pulang, kembali' 'sudah kembali'

$$
\begin{aligned}
& \text { limba }+\{-\mathrm{mo}\}-\text { limbamo } \\
& \text { 'keluar' 'sudah keluar' } \\
& \text { ari }+\{\text {-mo }\}-\text { arimo } \\
& \text { 'sudah, selesai' 'pernah' } \\
& \text { bele }+\{\text {-mo }\}-\text { belemo } \\
& \text { 'miring, serong' 'terbenam' }
\end{aligned}
$$

\subsection{Sufiks $\{-$ no $\}$}

Unsur $\{-$ no $\}$ dalam bahasa Kulisusu memiliki dua fungsi, yaitu sebagai afiks dan klitika. Jika melekat pada nomina unsur ini berfungsi sebagai klitika yang memiliki makna pronominal persona dan pronominal benda yang menyatakan milik (dalam bahasa Indonesia dapat disejajarkan dengan klitika \{nya)). Lihat contoh di bawah.

raha 'rumah' + $\{$-no $\}$ - rahano 'rumahnya' tampu 'ujung' + \{-no\}-tampuno 'ujungnya' tama 'bapak' + \{-no $\}$ - tamano 'bapaknya'

Sebagai afiks, sufiks $\{-$ no $\}$ dapat melekat pada adjektiva dan verba yang berfungsi sebagai pembentuk kata sandang untuk membendakan (menominalkan) kata jadian seperti yang tersebut pada kata dasarnya. Perhatikan contoh berikut.

$$
\begin{aligned}
& \text { molori }+\{- \text { no }\}-\text { molorino } \\
& \text { 'mulus' 'yang mulus' } \\
& \text { mokahi }+\{- \text { no }\}-\text { mokahino } \\
& \text { 'kasar' 'yang kasar' } \\
& \text { mangka + }\{- \text { no }\}-\text { mangkano } \\
& \text { 'menangis' 'yang menangis' } \\
& \text { sagiu + } \text {-no }\} \text { - sagiuno } \\
& \text { 'lain' 'yang lain' }
\end{aligned}
$$

Berdasarkan beberapa contoh tersebut dapat dilihat bahwa sufiks $\{-$ no $\}$ hanya memiliki satu bentuk varian, yiatu $\{-n o\}$.

\subsection{Sufiks \{-ano\}}

Sufiks ini berfungsi membentuk kelas verba dan nomina. Sufiks ini memiliki dua makna. Jika kata dasar yang dilekati berkategori verba, makna dari sufiks adalah menyatakan 'akibat dari apa yang tersebut pada bentuk dasarnya'. Perhatikan contoh di bawah ini. cuuna $+\{$-ano $\}-$ cuunaano 
'jatuh' 'akibat dari jatuhnya'

pangka $+\{$-ano $\}-$ pangkaano

'menangis' 'akibat dari menangis'

Jika kata dasar yang diimbuhi berkategori adjektif, sufiks ini bermakna 'tempat seperti yang tersebut pada bentuk dasarnya'. Lihat contoh berikut.

doloma $+\{$-ano $\}$ - dolomahano

'gelap' 'tempat yang gelap'

ompudu $+\{$-ano $\}$ - ompuduhano

'pendek' 'tempat yang pendek'

Dari beberapa contoh dari sufiks $\{$-ano\} terlihat bahwa sufiks ini memiliki dua jenis alomorf, yaitu \{-ano\} dan \{-hano\}.

Berdasarkan paparan data sufiks-sufiks tersebut dapat dikemukakan bahwa sufiks bahasa Kulisusu memiliki variasi yang relatif banyak. Proses pengaidahannya pun cenderung rumit karena semua bunyi vokal dari bunyi akhir bentuk dasar berpengaruh ke alomorf yang dihasilkan. Keterbatasan bunyi vokal menyebabkan perubahan yang terjadi dalam morfofonemik tersebut cenderung manasuka atau tidak teratur. Bahkan, dalam kasus-kasus tertentu, ada bentuk jadian yang hanya ditemukan satu contoh untuk sebuah alomorf. Inilah yang menjadi salah satu keunikan dari bahasa Kulisusu.

Inilah yang disebutkan sebelumnya bahwa bahasa Kulisusu dalam morfofonemik sufiksnya, alomorfnya (alternasi) tidak dapat disistemkan dan diramalkan. Sifat tidak tetap dari alomorf yang terbentuk dapat dilihat dalam beberapa data yang sudah dipaparkan.

Dalam paparan data tersebut juga dapat dilihat bahwa ada sufiks yang relatif banyak memiliki alomorf, ada juga yang sedikit alomorfnya, bahkan ada yang hanya memiliki satu jenis alomorf.

\section{Simpulan}

Berdasarkan permasalahan dan pembahasan yang diuraikan dalam penelitian dapat diambil beberapa kesimpulan bahwa ada sufiks yang memiliki beberapa makna . Selain itu, variasi bentuk atau alomorf dari sebuah sufiks ada yang produktif, seperti sufiks $\{-\mathrm{a}\},\{-\mathrm{i}\}$, dan $\{-$ ako\}. Sementara, ada juga yang hanya memiliki satu dan dua bentuk varian, yaitu $\{-\mathrm{o}\},\{-$ ano $\},\{-$ mo\}, dan $\{-$ no $\}$.

Sufiks $\{$-a $\}$ jika melekat pada bentuk dasar dapat memiliki makna 'tempat', 'alat atau perlengkapan', 'hasil dari tindakan' dan bermakna 'waktu atau masa'. Dalam proses morfofonemik, sufiks $\{$-a $\}$ memiliki alomorf yang relatif banyak, yaitu $\{-\mathrm{a}\},\{-\mathrm{ka}\},\{-\mathrm{ha}\},\{-\mathrm{ta}\},\{-$ ya\}, \{-la\}, \{-sa\}, \{-pa\}, \{-ma\}, \{-ra\}, dan $\{$-pia $\}$.

Sufiks berikutnya yang memiliki banyak varian adalah sufiks $\{-\mathrm{i}\}$, yaitu $\{-\mathrm{i}\},\{-\mathrm{wi}\},\{-\mathrm{ki}\},\{-$ si $\},\{-n i\},\{-r i\},\{-p i\},\{-n i\},\{-c i\},\{-m i\}$, dan $\{-l i\}$. Sufiks ini memiliki beberapa makna, yaitu 'melakukan perbuatan, 'memanggil atau mencari', 'melakukan pekerjaan atau perbuatan', 'memberikan sesuatu', 'membuat atau menjadikan sesuatu'.

Bentuk variasi yang produktif juga ditemukan dalam sufiks $\{-$ ako\}, yaitu $\{-a k o\},\{-$ hako\}, \{-pako\}, \{sako\}, \{-lako\}, \{-kako\}, \{-tako\}, \{-rako\}, \{-mako\}, dan $\{-$ yako\}. Jika melekat pada bentuk dasar, sufiks ini memiliki beberapa makna, yaitu 'menjadikan', dan 'melakukan pekerjaan'.

Sufiks \{-o\} menyatakan arti 'perintah melakukan pekerjaan atau menekankan makna kata yang di depannya dalam bentuk perintah'. Sufiks ini hanya memiliki dua varian, yaitu $\{-0\}$ dan $\{$-ho\}. Berikutnya adalah sufiks $\{$-ano\} yang bermakna 'akibat' dan 'tempat'. Sufiks ini hanya memiliki dua varian, yaitu $\{-$-ano\} dan $\{-$ hano\}.

Sufiks $\{$-no\} berfungsi sebagai pembentuk kata sandang untuk membendakan (menominakan) kata. Sufiks ini hanya memiliki satu varian, yaitu $\{-$ no $\}$. Sama seperti sufiks $\{-\mathrm{mo}\}$ yang hanya memiliki satu varian. Sufiks ini 'menekankan pekerjaan sudah dilakukan'.

\section{Daftar Pustaka}

Akhyaruddin, Ageza Agusti, H. Y. 2020. Analisis Morfofonemik Bahasa Melayu Jambi sebagai Pengembangan Bahan Ajar Morfologi Bahasa 
Indonesia. dalam Pena: Jurnal Pendidikan Bahasa dan Sastra 9 (2):56-67.

Asmadi. 2016. Proses Morfologis pada Kultur Bahasa Etnis Samawa. Dalam Retorika 2 (2): 214-232. https://doi.org/10.22225/jr.22.58.214-232

Asmi. 1995. Sistem Afiksasi Bahasa Kulisusu. Kendari: Universitas Halu Oleo.

Chaer, A. 2015. Morfologi Bahasa Indonesia: Pendekatan Proses.Jakarta: Rineka Cipta.

Damayanti, W. 2015. Bentuk Derivasi Bahasa Melayu DialekSambas. Dalam Kandai 12(2): 255-268.

Firman A.D. 2017. Morfofonemik dalam Afiksasi Bahasa Moronene. Dalam Widyaparwa 45 (1): 47-67.

https://doi.org/10.26499/wdprw.v45i1.201

Hidayat, R. 2018. Kaidah Morfofonemik Bahasa Sumbawa Dialek Sumbawa Besar. Dalam Genta Bahtera 4 (1): 11-22 https://doi.org/10.47269/gb.v4i1.42

http://arum-sultra.blogspot.com/2011 /02/. 2011. Kawasan Buton Utara Masa Praintegrasi ke Kesultanan Buton. Diakses 2Maret 2013

Jerniati. 2017. Morfofonologi dalam Konstruksi Bahasa Mandar: Perspektif Fonologi Generatif. Dalam Sawerigading 23(2): 241-251.

Kantor Bahasa Sulawesi Tenggara. 2016. La Kino Nambo (Cerita Rakyat Kulisusu). Kendari: Kantor BahasaSulawesi Tenggara.

Kantor Bahasa Sulawesi Tenggara. 2017. Cerita Rakyat Wawonii. Kendari: Kantor Bahasa Sulawesi Tenggara.

Mead, D. 2016. Kamus Kulisusu (Kulisusu-IndonesiaInggris). Edisi Percobaan ke-7. (http://www.kulisusu.net). Diakses 14
Desember 2017.

Moleong, L. J. 2017. Metodologi Penelitian Kualitatif. Bandung: Remaja Rosdakarya.

Parera, J. D. 2007. Morfologi Bahasa. Jakarta: Gramedia PustakaUtama.

Paryono, Y. 2010. Morfofonemik Bahasa Jawa Dialek Banyumas. Dalam Widyariset 13(1):173-181.

Pusat Bahasa. 2008. Bahasa dan Peta Bahasa di Indonesia. Jakarta: Pusat Bahasa, Departemen Pendidikan dan Kebudayaan.

Putrayasa, I. B. 2017. Kajian Morfologi: Bentuk Derivasional dan Infleksional (Edisi II). Bandung: Refika Aditama.

Ramsi, I. S. K. 2017. Infleksi dalam Bahasa Kulisusu. Dalam Bastra $1 \quad$ (4): $\quad 1-8$ ojs.uho.ac.id/index.php/BASTRA/article

Roy, M. 2007. Inflectional Verb in Kulisusu Language. Kendari:Universitas Halu Oleo.

Sarmin. 2015. Sistem Morfologi Nomina dalam Bahasa Kulisusu. Dalam Jurnal Humanika 15 (3): 1-16 ojs.uho.ac.id/index.php/ HUMANIKA/article

Sudaryanto. 2015. Metode dan Aneka Teknik Analisis Bahasa. Yogyakarta: Sanata Dharma University Press.

Sugerman. 2016. Morfologi Bahasa Indonesia: Kajian ke Arah Linguistik Deskriptif. Yogyakarta: Penerbit Ombak.

Sundasewu, R. U. 2015. Analisis Kontrastif Perubahan Fonem pada Proses Reduplikasi dalam Bahasa Jepang dan bahasa Indonesia: Kajian Morfofonemik. Dalam Edusentris 2 (2): 190-202. https://doi.org/10.17509/edusentris.v2i2.171 